\title{
Skilda ojämlikhetsregimer? Praktikerna på kvinno- och mansdominerade arbetsplatser
}

\author{
Kristina Boréus, Alireza Behtoui, Ulf Mörkenstam, \\ Anders Neergaard \& Soheyla Yazdanpanah
}

\section{Ojämlikhet på kvinno- och mansdominerade arbetsplatser}

Nej, för att det är orealistiskt du vet, du själv har ju varit där på [huvud]kontoret, du ser, det finns inga invandrare som jobbar där. Så jag snackar inte skit, så är det, det är verkligheten. [...] Jag försöker inte, för att varför ska jag söka när jag kommer att få nej.

Citatet kommer från en intervju med en fastighetsskötare på ett kommunalt bostadsföretag, Bostadsbolaget som vi kallar det, där vi genomförde en studie om ojämlikhet (Boréus \& Mörkenstam 2010, 2015). Denne fastighetsskötare hade lång erfarenhet av administrativt arbete från sitt tidigare hemland i Latinamerika och ville nu byta till ett liknande arbete. Men han hade inte sökt någon sådan befattning eftersom han var inställd på att få nej. Han hade iakttagit att "invandrare" helt enkelt inte fick vissa slags tjänster.

I en studie ${ }^{1}$ på ett äldreboende i en större svensk stad berättade en undersköterska som invandrat från ett land i Asien för forskaren om hur dåligt hon mådde på jobbet och att hon var trött på att behandlas "som skit”. ”Jag är trött på att gå och be för att få extra timmar", sa hon. Hon menade att invandrad personal diskriminerades, till exempel genom att svenskfödda undersköterskor som ville ha extratimmar gavs företräde (Behtoui m.fl. 2016, 2017). ${ }^{2}$ 
Gemensamt för fastighetsskötaren och undersköterskan var deras bakgrund i det globala syd. De tillhörde en minoritet i förhållande till de svenskfödda anställda. Oavsett vilken utbildningsväg de gått innan de utvandrade hade de numera även det gemensamt att de befann sig i arbetarklassyrken. De hade tillsammans med svenskfödda anställda i samma jobb en arbetarklassposition på sin arbetsplats, med allt vad det innebär av underordning under chefer och mellanchefer (se Hörnqvist 2019 om klasskillnader på arbetsmarknaden och på arbetsplatser). En skillnad mellan dem var att fastighetsskötaren arbetade på en mansdominerad och undersköterskan på en kvinnodominerad arbetsplats, det vill säga arbetsplatser där män respektive kvinnor dominerade antalsmässigt.

Genomgående visar den internationella forskningen att vissa minoritetsgrupper missgynnas i arbetslivet: invandrade till länder i det globala nord, religiösa minoriteter, grupper med rötter i andra delar av världen liksom minoriteter med en historia av förtryck, såsom afroamerikaner i USA. Ofta har dessa grupper lägre löner, sämre arbetsvillkor och sämre arbetstrygghet (Behtoui \& Neergaard 2010; Rödin 2011). I Sverige har invandrade från det globala syd lägre löner än infödda personer (le Grand \& Szulkin 2002) och tenderar att ha lägre befattningar (Åslund \& Nordström Skans 2010). Utlandsfödda är också överrepresenterade bland anställda med tidsbegränsade anställningar (Bursell 2019).

En annan genomgående ojämlikhet $i$ arbetslivet är den mellan kvinnor och män. Kvinnor är överrepresenterade i lågbetalt arbete, tjänar mindre än män i samma yrke eller i yrken som kräver motsvarande kompetens och stöter på fler hinder för att göra karriär. O’Reilly m.fl. $(2015,301)$ jämförde lönegapet mellan kvinnor och män i en rad länder: gapet varierade starkt men var år 2012 exempelvis 30 procent i Estland och kring 20 procent i flera andra europeiska länder samt USA. Som en förklaringsfaktor nämner författarna arbetsmarknadens segregering kvinnor återfinns i lägre betalda yrken. Samtidigt visar forskning att de jobb som innehas av kvinnor värderas lägre (Reskin \& Bielby 2005).

Detta kapitel handlar om båda dessa typer av ojämlikhet: mellan anställda födda i olika länder och mellan kvinnor och män. Vi undersöker hur sådana ojämlikheter uppstår och består på arbetsplatser. Enskilda arbetsplatser inkorporerar praktiker och föreställningar från 
det omkringliggande samhället. Men där utvecklas också lokala sätt att agera och tänka. Ojämlikhet på enskilda arbetsplatser mellan personer som tenderar att kategoriseras i olika grupper kan analyseras med hjälp av begreppet "ojämlikhetsregim". Som framgått av bokens inledningskapitel är ojämlikhetsregimer system av praktiker, agerande och föreställningar som leder till och upprätthåller ojämlikhet exempelvis mellan kvinnor och män, mellan människor med olika hudfärg eller kulturell bakgrund och mellan personer i olika samhällsklasser (Acker 2006, 2009). Vi har studerat vilka typer av ojämlikhet arbetsplatsernas ojämlikhetsregimer rymmer och vad i arbetsorganisationen som ger upphov till dessa ojämlikheter.

\section{Syfte och forskningsfrågor}

Vi kommer i detta kapitel att jämföra ojämlikhetsregimerna på en mansdominerad arbetsplats med dem på några kvinnodominerade arbetsplatser. Samtliga arbetsplatser hade en minoritet invandrade anställda. Syftet med jämförelsen är att öka kunskapen om hur ojämlikhet (re)produceras inom olika typer av ojämlikhetsregimer på svenska arbetsplatser.

Vår första forskningsfråga är om det fanns skillnader i vilka typer av ojämlikhet som återfanns på den mansdominerade arbetsplatsen och de kvinnodominerade arbetsplatserna. Med "typer av ojämlikhet" syftar vi både på mellan vilka grupper ojämlikhet råder (till exempel mellan kvinnor och män) och vad det är som är ojämlikt (exempelvis löner).

Vår andra forskningsfråga är hur den ojämlikhet mellan olika grupper vi funnit kan förklaras. Vi utgår från ett relationellt synsätt som utvecklats av bland andra Charles Tilly, Joan Acker och Donald Tomaskovic-Devey. Framför allt använder vi oss av två analysbegrepp. Dels "resursanspråk" (claims-making): individer och grupper gör anspråk på löner, arbetsvillkor och annat i en arbetsorganisation. Dels "social stängning" (social closure): anställda i vissa grupper stänger andra ute och monopoliserar förmåner på arbetsplatsen.

I nästa avsnitt presenterar vi tidigare forskning om ojämlikhet på kvinno- respektive mansdominerade arbetsplatser samt den relationella utgångspunkten för att analysera ojämlikhet i arbetslivet. Sedan 
presenterar vi de empiriska studierna. Därefter redogör vi för vår empiriska studie och för de ojämlikheter vi fann, jämför de två typerna av arbetsplatser och söker förklara de mönster vi iakttog med hjälp av begreppen "resursanspråk" och "social stängning". Slutligen reflekterar vi över vad resultaten kan säga oss om olika slags ojämlikhetsregimer.

\section{Glastak och glasrulltrappor}

Vad innebär det att vara kvinna på en mansdominerad arbetsplats såsom kvinnlig fastighetsskötare på Bostadsbolaget - eller att vara man på en kvinnodominerad arbetsplats - såsom manlig undersköterska inom äldreomsorgen? Enligt teorin om tokenism riskerar en minoritet i en arbetsorganisation att utsättas för tryck på grund av sin synlighet och avvikelse och pressas mot assimilering (Moss Kanter 1977/1993).

Tokenismteorin har dock ifrågasatts. Ackers (1990) och flera andra feministiska forskares (Martin 2003; Ott 1989; Williams 1993; Yoder 1991) kritik handlar om att Moss Kanter betraktar organisationer som könsneutrala. I själva verket är arbetsorganisationer viktiga samhällsarenor för att konstruera och praktisera ojämlika könsrelationer (Martin 2003; Reskin \& Bielby 2005). Budig (2002) prövade tokenismen empiriskt på ett longitudinellt enkätmaterial från arbetslivet i USA. Resultaten pekade mot att teorin inte stämde: män var privilegierade i såväl lön som löneutveckling vare sig de arbetade på mansdominerade, könsbalanserade eller kvinnodominerade arbetsplatser. På motsvarande sätt visade Malin \& Wise (2018) utifrån ett tyskt material att män med större sannolikhet än kvinnor får ledande positioner i en rad yrken, oavsett om dessa är kvinno- eller mansdominerade eller har en jämn könsfördelning. I en studie av manliga avdelningschefer i svensk äldreomsorg konstaterade Hagerman m.fl. (2015) att ingen av de intervjuade männen nämnde någon nackdel med att vara i minoritet.

Dessa resultat ifrågasätter alltså idén att minoritetsgrupper på en arbetsplats alltid missgynnas, men de är förenliga med idéerna om glastak (glass ceiling) och om glasrulltrappor (glass escalator). Glastaket är de strukturella hinder som gör det svårt för kvinnor att få ledande positioner i arbetsorganisationer. Glasrulltrappan gör det lättare för män än för kvinnor att stiga i befattning eller höja sin lön på kvinno- 
dominerade arbetsplatser; begreppet lanserades av Williams (1992) i en artikel om dolda fördelar för män på kvinnodominerade arbetsplatser. Yavorsky m.fl. (2016) sammanställde forskning som visade att män har svaga incitament att välja lågbetalda kvinnodominerade yrken men att de som gör det ofta får fördelar gentemot kvinnorna på dessa arbetsplatser - de kan ta glasrulltrappan uppåt. Forskarna pekar dock även på att män från etniska minoriteter återfinns i lågstatusjobb i USA, medan majoritetsmän tenderar att ha bättre betalda jobb och att minoritetsmännen arbetar på arbetsplatser med fler kvinnor. Även om män kanske åtnjuter vissa dolda fördelar på kvinnodominerade arbetsplatser väger det inte upp nackdelarna med att arbeta i ett kvinnodominerat yrke (Yavorsky m.fl. 2016). Woodhams m.fl. (2015) konstaterade i en studie av brittiskt arbetsliv att män från etniska minoritetsgrupper mer sannolikt än andra män återfanns inom kvinnodominerade lågstatusyrken.

Williams (2013) har senare justerat föreställningen om glasrulltrappan genom att peka på att den inte är tillgänglig för män från etniska minoritetsgrupper (vilket alltså Yavorsky m.fl. (2016) hävdar att den är i begränsad utsträckning) och att den bara finns att tillgå i vissa jobb, nämligen de där det alls går att göra karriär.

Forskningen pekar alltså mot att män som inte tillhör någon utsatt minoritet gynnas på kvinnors bekostnad på både mans- och kvinnodominerade arbetsplatser. Den pekar också mot att både kvinnor och män som inte anses tillhöra den majoritetsetniska gruppen missgynnas. Det är det övergripande mönstret, men Tomaskovic-Devey \& Avent-Holt (2019) påpekar att det finns stora variationer både mellan länder och mellan arbetsorganisationer. Mönstret är till och med det omvända i vissa organisationer, det vill säga att kvinnor och anställda från etniska minoritetsgrupper privilegieras.

\section{En relationell ansats för att studera ojämlikhetsregimer}

Tomaskovic-Devey (2014) samt Tomaskovic-Devey \& Avent-Holt (2019) presenterade ett relationellt sätt att analysera hur ojämlikhet produceras, återskapas och förändras inom arbetsorganisationer, en utveckling av en 
modell som hade presenterats av Charles Tilly (1998) och var besläktad med Joan Ackers (2006) beskrivning av ojämlikhetsregimer.

Ojämlikhetsregimerna formas för det första av vilka resurser som finns att fördela. På de arbetsplatser vi studerade, ett kommunalt bostadsbolag samt kommunalt och privat ägda äldreboenden som ingår i kommunens äldreomsorg, är det i huvudsak politiskt fördelade skatteintäkter som utgör resurserna. För det andra formas de av arbetsplatsens uppgiftsbaserade relationer (vem gör vad?) samt klass- och statusbaserade sociala relationer (Tomaskovic-Devey \& Avent-Holt 2019). För det tredje formas de enligt Tomaskovic-Devey \& Avent-Holt (2019) liksom Acker (2006) av de formella och informella praktiker som följs på arbetsplatserna, och för det fjärde av "kulturella modeller av människor, arbete och ojämlikhet" (Tomaskovic-Devey \& Avent-Holt 2019, 70) i samhället i stort. ${ }^{3}$

Inte minst den fjärde punkten pekar på hur livet på arbetsplatsen samspelar med det omgivande samhället. Centrala här är så kallade kategoriska distinktioner, det vill säga indelningar som har stor samhällelig betydelse: kvinnor skiljs från män, samhällsklasser från varandra, invandrade från infödda, personer med olika religion från varandra och så vidare (Tomaskovic-Devey 2014). Vilka kategoriska distinktioner som görs skiljer sig åt mellan tider och platser. Stainback m.fl. (2010) lyfter fram betydelsen av den omgivning som en arbetsorganisation verkar i och postulerar att denna, tillsammans med den tröghet som finns i varje organisation och den relativa makten hos olika aktörer på arbetsplatsen, förklarar varför ojämlikhet upprätthålls eller förändras.

På arbetsplatsen gör olika grupper och individer anspråk på de samlade resurserna. Resursanspråken kan uttryckas under lönesamtal, när någon söker en befordran och så vidare. De kan framföras på gruppbasis, såsom när en fackförening förhandlar om löner eller arbetsvillkor, eller individuellt, som när en chef beordrar en underlydande att utföra en viss uppgift och därmed gör anspråk på dennas arbetskraft (Tomaskovic-Devey \& Avent-Holt 2019). Resursanspråk framförs inom ramen för en lokal kultur som härbärgerar föreställningar om vad som gör någon mer eller mindre förtjänt. Individer med lägre status har svårare att få igenom sina resursanspråk. 
Social stängning är den process där en grupp gör kategoriska distinktioner mellan sig själva och andra för att exkludera de andra från resurser. Diskriminering utifrån kön, hudfärg, födelseland och andra föreställda eller verkliga egenskaper ger upphov till exkludering (Tomaskovic-Devey \& Avent-Holt 2019). Exkludering på arbetsplatser kan påverka tillgången till högre löner, eftertraktade arbetsuppgifter och förmånligare arbetsscheman.

\section{Studierna av Bostadsbolaget och äldreomsorgen}

Studien av den mansdominerade arbetsplatsen Bostadsbolaget (ett kommunalt bostadsföretag i en större svensk kommun) genomförde vi i flera faser under perioden 2005-2009. Bostadsbolaget hade 110 anställda, varav en tredjedel arbetade på huvudkontoret och de övriga på bolagets fem områdeskontor i olika bostadsområden. På huvudkontoret jobbade mest tjänstemän, medan flertalet anställda vid områdeskontoren var fastighetsskötare. Arbetet på respektive områdeskontor leddes av en områdeschef och arbetet styrdes övergripande av en vd och en ledningsgrupp.

Fastighetsskötarna hade ansvar för skötseln av lägenheterna och deras omgivning, liksom för kontakten med hyresgästerna. I deras uppgifter ingick att utföra reparationer; se till att tvättstugor, hissar och garage var i ordning; hålla rent utomhus kring byggnaderna samt visa upp lägenheterna för potentiella hyresgäster. När vi inledde studien hade alla fastighetsskötare generellt samma uppgifter, även om de tillämpade viss arbetsdelning.

Fastighetsskötarna stod i centrum för vår studie, men vi undersökte också fördelningen av befattningar och löneskillnader på hela företaget. Vi jämförde för det första arbetsvillkoren för kvinnor och män. För det andra jämförde vi villkoren för anställda som fötts och vuxit upp i Sverige med villkoren för anställda som invandrat till Sverige efter femton års ålder. Av de utlandsfödda fastighetsskötare som ingick i studien var alla utom två födda i Afrika, Asien eller Latinamerika, det vill säga i det globala syd. Det fanns bland fastighetsskötarna endast en utlandsfödd kvinna. Därför talar vi om tre grupper i studien: svenskfödda män, svenskfödda kvinnor och utlandsfödda män. 
Intervjuer genomfördes vid fyra av de fem områdeskontoren. Sammantaget intervjuade vi där 10 av 11 invandrade manliga fastighetsskötare, 10 av 12 kvinnliga fastighetsskötare och 10 av 24 svenskfödda manliga fastighetsskötare, samt tre områdeschefer. Vi genomförde även tre fokusgruppssamtal med fastighetsskötare. ${ }^{4}$

I den empiriska undersökningen ingick även deltagande observation. Under två dagar gick vi med två fastighetsskötare som visade oss sitt arbete, och vi deltog i sexton arbetsplatsträffar där fastighetsskötarna och deras områdeschefer gick igenom och diskuterade arbetet. Utöver detta genomförde vi en enkät med 89 anställda från olika yrkesgrupper vid några arbetsplatsträffar samt analyserade interna och externa dokument som jämställdhetsplaner, lönelistor, arbetsbeskrivningar och företagets egna enkäter om hur de anställda trivdes på sin arbetsplats.

Studien av de kvinnodominerade arbetsplatserna i äldreomsorgen genomförde vi 2012-2014 vid äldreboenden i en större svensk kommun. I likhet med många andra kommuner hade staden där vår studie genomfördes lagt ut äldreomsorgen på entreprenad, vilket innebar att privata vårdföretag och kommunens egna boenden måste konkurrera i upphandlingar (Erlandsson m.fl. 2013). Både sorters boenden ingår i studien.

På dessa arbetsplatser arbetade vårdbiträden, med enbart grundskola bakom sig, samt undersköterskor, som gått treårigt omvårdnadsprogram på gymnasiet. Det dagliga arbetet på boendenas olika avdelningar leddes av en teamledare som var undersköterska. På boendena fanns också sjuksköterskor som ansvarade för två eller tre avdelningar. Varje boende styrdes av en verksamhetschef.

Vi fann inga formella skillnader mellan vårdbiträdenas och undersköterskornas uppgifter. De var ansvariga bland annat för att förbereda och servera måltiderna (samt att mata vissa boende), dela ut mediciner och hjälpa de boende med deras personliga hygien. Dessutom hade de andra arbetsuppgifter, såsom köksarbete, tvätt, städning av gemensamma lokaler och dagliga aktiviteter med de äldre. Nästan alla var kontaktperson gentemot de anhöriga för minst en boende, vilket innebar att de hade ansvar för städningen av den boendes rum samt inköp av hygienartiklar, underkläder med mera och att de följde med den boende till sjukhus och tandläkare vid behov. De flesta undersköterskor och vårdbiträden 
hade ett eller flera extraansvar såsom miljöombud, kostombud, aktivitetsombud, brandombud, palliativt ombud eller inkontinensombud. En annan arbetsuppgift var att digitalt dokumentera det dagliga arbetet och de boendes situation.

Studien fokuserade på vårdbiträden samt undersköterskor. Vi jämförde kvinnors och mäns arbetsförhållanden. I ytterligare en jämförelse delade vi in de anställda i fyra grupper: svenskfödda med svenskfödda föräldrar; födda i Västeuropa och Nordamerika; födda i Östeuropa; födda i Afrika, Asien eller Latinamerika (det globala syd).

Vi intervjuade 30 anställda, i huvudsak undersköterskor och sjukvårdsbiträden, varav vissa var teamledare. Av de 30 var 15 svenskfödda kvinnor, 10 utlandsfödda kvinnor, 4 utlandsfödda män och en svenskfödd man. Utöver detta intervjuade vi dessa anställdas verksamhetschefer. ${ }^{5}$

En forskare ägnade sig åt deltagande observation under sju-åtta dagar på vardera tre avdelningar på två äldreboenden, det ena privat och det andra kommunägt. Liksom i studien av Bostadsbolaget gjorde vi observationer vid ett antal arbetsplatsträffar och studerade olika typer av dokument.

I studien ingick även en telefonenkät med 304 anställda vid samtliga äldreomsorgsenheter i kommunen. Vi tog fram frågorna men intervjuerna genomfördes av intervjuare från SCB. Enkäten kompletterades med registeruppgifter från SCB.

\section{Ojämlikheter på de studerade arbetsplatserna}

Resultaten av studierna visade på systematiska ojämlikheter mellan infödda anställda och (vissa av) de invandrade anställda, liksom vissa ojämlikheter mellan kvinnliga och manliga anställda. Ojämlikheterna var av flera slag. ${ }^{6}$

\section{Fördelning av befattningar}

På alla de undersökta arbetsplatserna var könsfördelningen alltså ojämn med en majoritet anställda av det ena könet och en majoritet av de anställda födda i Sverige. 
Av de 62 fastighetsskötarna var 79 procent män och på Bostadsbolaget i sin helhet var andelen män 64 procent. Arbetsdelningen var traditionell: de befattningar där administration och HR-uppgifter var centrala arbetsuppgifter innehades till 80 procent av kvinnor, medan de befattningar där tekniska uppgifter var centrala till 85 procent innehades av män. I andra befattningar där kontakt med människor var viktig, såsom receptionsarbete och felanmälan, var nio av tio anställda kvinnor. Lika många kvinnor som män innehade ledningsfunktioner - kvinnor var alltså överrepresenterade i förhållande till sin andel i företaget - men vd för företaget var en man. Vi tolkade inte könsarbetsdelningen i sig som ett uttryck för ojämlikhet mellan kvinnor och män eftersom den inte uppenbart missgynnade någon av grupperna.

Av fastighetsskötarna var 73 procent födda i Sverige och av de anställda på hela företaget 82 procent. Även etnisk arbetsdelning rådde. Invandrade anställda var underrepresenterade i arbetsledande positioner men överrepresenterade i arbetaryrket fastighetsskötare. Ingen i ledningen hade invandrat till Sverige. Detta betraktar vi som en ojämlik befattningsfördelning.

Påäldreomsorgsarbetsplatserna var könsasymmetrin ännu starkare: 88 procent av de anställda var kvinnor, enligt telefonenkäten. Till skillnad mot på Bostadsbolaget fann vi här ingen yrkesmässig könsarbetsdelning mellan de anställda. På ledningspositioner var exempelvis 88 procent kvinnor, det vill säga samma andel som bland samtliga anställda.

De infödda utgjorde 67 procent av de anställda på äldreomsorgsarbetsplatserna. Liksom på Bostadsbolaget rådde etnisk arbetsdelning: anställda från det globala syd var underrepresenterade i de mer kvalificerade befattningarna, såsom sjuksköterska, men överrepresenterade i den minst kvalificerade befattningen, sjukvårdsbiträde. Svenskfödda anställda innehade 89 procent av ledningspositionerna. Personer födda i det globala syd utgjorde nästan 27 procent av de anställda men endast 11 procent innehade någon ledningsposition. En bearbetning av enkätoch registerdata visade att utbildning och att ha svenska betyg (till skillnad från kvalifikationer från ett annat land) förklarade en del av befattningsojämlikheten, men inte hela. 


\section{Löner}

Bostadsbolaget jämförde löpande löneutvecklingen för kvinnor och män i samma befattningar, och personer i ledningen uttryckte stolthet över att kvinnor inte var lönediskriminerade. När vi delade in fastighetsskötarna i tre kategorier - infödda män, infödda kvinnor och utlandsfödda män - framträdde dock en ojämlikhet: de svenskfödda manliga fastighetsskötarna låg över övriga. De hade en medellön på 22959 kr, medan de kvinnliga fastighetsskötarnas medellön var $22642 \mathrm{kr}$. Lägst låg de invandrade manliga fastighetsskötarna med medellönen 22308 kr. Dessutom missgynnades utlandsfödda anställda lönemässigt av den ojämlika befattningsfördelningen. De tre typer av befattningar där de var underrepresenterade - inom ledningen, ekonomiadministrationen och personalavdelningen - var de högst avlönade på Bostadsbolaget.

Lång tid i Bostadsbolaget var ingen garanti för de kvinnliga eller invandrade fastighetsskötarna att deras löner skulle vara i paritet med de infödda manliga fastighetsskötarnas. De utlandsfödda manliga fastighetsskötarna hade de lägsta medellönerna vare sig de varit anställda mer än 10 år, i 6-10 år eller mindre än 6 år. Löneskillnader kan också motiveras med utbildningsbakgrund. Här saknar vi fullständiga data. De data vi har pekar dock inte mot att högre lön motiverades av längre utbildning. Bland de 29 fastighetsskötare vi intervjuade hade de invandrade männen i genomsnitt något längre utbildning än kvinnorna, vilka i sin tur hade något längre utbildning än de infödda männen. (Utbildningarnas precisa innehåll saknar vi också kunskap om.)

På de kvinnodominerade arbetsplatserna fann vi efter kontroll för utbildning, total arbetserfarenhet och arbetserfarenhet inom vården inga statistiskt säkerställda skillnader mellan kvinnors och mäns löner. Däremot fann vi en sådan skillnad mellan anställda från det globala syd och övriga. Anställda från det globala syd hade cirka 9 procent lägre lön än de svenskfödda med samma utbildning och arbetslivserfarenhet, vilket motsvarade mer än $2000 \mathrm{kr}$ i månaden. 


\section{Rädsla för att framföra kritik}

Vår undersökning blottlade en ojämlikhet som troligen hade att göra med hur säkra eller osäkra personer i olika kategorier kände sig på arbetsplatsen. Meningarna gick isär bland de intervjuade fastighetsskötarna om hur pass öppet klimatet på Bostadsbolaget var. Många, framför allt infödda manliga anställda, uppfattade att det var högt $\mathrm{i}$ tak och att man inte var rädd för att ta upp vad som helst på arbetsplatsträffarna. Många kvinnliga och utlandsfödda fastighetsskötare var mindre positiva. Som en utlandsfödd fastighetsskötare uttryckte det: "Jag har ingen kritik mot företaget, men om jag skulle framföra kritik kan det bli svårt. Kanske får jag sparken!” Enkäten med 89 anställda visade också att infödda män kände sig säkrare vad gällde att uttrycka kritik än både kvinnor och utlandsfödda män.?

Även på de kvinnodominerade äldreomsorgsarbetsplatserna fann vi en signifikant skillnad mellan anställda från det globala syd och andra vad gällde i vilken utsträckning man kände sig bekväm med att framföra kritik till sina chefer. ${ }^{8}$ Bland de svenskfödda respondenterna valde 60 procent svarsalternativet "Ja, i hög grad", bland respondenterna från det globala syd bara 42 procent. Till skillnad från på Bostadsbolaget fann vi ingen statistiskt säkerställd skillnad mellan kvinnor och män på denna punkt.

Vår första forskningsfråga kan nu besvaras. Det fanns en likhet mellan den mansdominerade arbetsplatsen och de kvinnodominerade $i$ att invandrade anställda, i synnerhet från det globala syd, missgynnades på flera sätt. En skillnad var att kvinnor enbart missgynnades på den mansdominerade arbetsplatsen, och där endast i relation till svenskfödda män. Jämförelsen redovisas mer detaljerat i tabell 9.1 (sid 231).

\section{Relationella förklaringar till ojämlikheterna}

Hur kan de ojämlikheter vi fann förklaras? I detta avsnitt analyserar vi dem med hjälp av begreppen "resursanspråk" och "social stängning". Här rör vi oss närmare livet på arbetsplatserna och använder oss av våra transkriberade intervjuer och fältanteckningar. 


\section{Resursanspråk}

"Både möjligheten att göra anspråk på något och anspråkets legitimitet reflekterar de sociala status- och maktrelationer som är associerade med individuella kompetenser, individuell makt och gruppmakt", skriver Donald Tomaskovic-Devey och Dustin Avent-Holt $(2019,164)$.

Det fanns en specifik individuell kompetens som var ojämnt fördelad mellan infödda och invandrade och som spelade roll för ojämlikheten: såväl på Bostadsbolaget som på äldreboendena tillmättes förmågan att tala och skriva god svenska stor betydelse. På Bostadsbolaget uppgav flera invandrade fastighetsskötare som vi intervjuade att ett argument som företaget använde för att bemöta deras löneanspråk var att de hade brister i sina svenskkunskaper. Det argumentet kunde kritiseras även av deras svenskfödda kolleger:

Men jag har en arbetskamrat här som är... Bara för att han inte pratar och skriver så bra svenska så har han mycket sämre lön än vi andra har men han kan fan så mycket mer än vad jag kan om det, det här vi behöver skruva på och var grejer finns och allt sånt här.

På äldreomsorgsarbetsplatserna kom frågan om svenska språket upp i flera intervjuer och i den deltagande observationen. Den bristande förmåga att uttrycka sig på svenska som de överordnade tillskrev vissa anställda kunde direkt påverka befattningsfördelningen. Två personer som under flera år arbetat som undersköterska respektive sjukvårdsbiträde tilldelades städuppgifter istället för att få fortsätta arbeta med de gamla. Den ena ställdes inför ett ultimatum att förlora jobbet om hon inte förbättrade sin svenska.

En annan individuell kompetens som var ojämnt fördelad mellan infödda och invandrade var relevant på Bostadsbolaget, nämligen förmågan att kommunicera med hyresgäster på andra språk än svenska. Praktiskt taget alla utlandsfödda fastighetsskötare vi intervjuade uppgav att de använde sina kunskaper i andra språk mer eller mindre ofta i sitt arbete. De använde dessa språk i sin egen kommunikation med hyresgäster men blev också regelbundet kontaktade av kolleger som inte lyckades kommunicera med hyresgäster med svaga svenskkunskaper. 
Ingen av dessa invandrade informanter uppfattade att dessa för Bostadsbolaget användbara språkkunskaper belönades i lönekuvertet. Hade de gjort det hade löneojämlikheten motverkats.

Resonemangen om hur de språkliga kompetenserna värderades gäller resursanspråk på individuell nivå. Men för lönesättningen spelade gruppmakt en viktig roll, uttryckt i de återkommande löneförhandlingarna mellan de fackliga organisationerna och arbetsgivarna, och organiseringsgraden är lägre bland utrikes än bland inrikes födda (Kjellberg 2019). Vad gäller löneskillnader är det även relevant att se till lagstadgade krav. Sedan 1994 är arbetsgivare skyldiga att göra en årlig lönekartläggning för att finna eventuella skillnader mellan kvinnors och mäns löner (Diskrimineringsombudsmannen 2020). Detta hade Bostadsbolaget och äldreomsorgen att ta hänsyn till. Det finns dock inget motsvarande krav för att säkerställa lönejämlikhet mellan anställda med bakgrund i olika länder. Det verktyg de invandrade anställda hade för att bekämpa löneojämlikhet var diskrimineringslagen, ett ytterst trubbigt instrument. Som Sahraoui visade i kapitel 6 var det i princip omöjligt för hennes informanter i Frankrike, Spanien och Storbritannien att kämpa mot orättvisor med hjälp av diskrimineringslagstiftningen. Mulinari (2015) beskriver att det finns en större beredvillighet i samhället att utmana könsojämlikhet än etnisk ojämlikhet. Kvinnors gemensamma strukturella position torde vara mer synlig och lättare att mobilisera kring än "invandrarskap".

Att göra relationella resursanspråk är den interaktiva process som sätter social exkludering i rörelse, skriver Tomaskovic-Devey \& AventHolt (2019). I nästa avsnitt redogör vi för sådant vi funnit på arbetsplatserna som visar på social stängning, kategorisk gränsdragning och monopolisering av resurser.

\section{Social stängning}

Social stängning är "en process genom vilken vissa grupper, implicit eller explicit, drar kategoriska gränser runt sig själva och andra för att monopolisera resurser" (Tomaskovic-Devey \& Avent-Holt 2019, 134).

På både Bostadsbolaget och äldreboendena kunde vi iaktta mer eller mindre kategoriska gränsdragningar mellan människor. Människor 
sorteras som kvinnor eller män överallt i samhället, inklusive på arbetsplatserna. Frågan är i vilken utsträckning upprätthållandet av dessa kategorigränser ledde till monopolisering av resurser.

På Bostadsbolaget fann vi alltså ojämlikheter mellan svenskfödda kvinnor och svenskfödda män: de kvinnliga fastighetsskötarna tjänade mindre än de manliga och upplevde det som svårare att framföra kritik till företaget. Föreställningar om skillnader mellan kvinnor och män kan ha bidragit till ojämlikheten. Exempelvis ifrågasatte ett par manliga fastighetsskötare sina kvinnliga kollegers tekniska förmåga. Det berättades också att hyresgäster ibland betvivlade de kvinnliga fastighetsskötarnas tekniska kompetens. En informant tog upp en annan förment skillnad mellan manliga och kvinnliga anställda: "Killar är mer ärliga, det är lättare att säga vad man tycker och tänker [...] Med tjejer är det inte lika lätt att ta kritik, kanske [...] Det är lite mer skitsnack, som jag kallar det." Vi hörde aldrig chefer eller andra anställda uttrycka att de gärna skulle se fler kvinnor i de traditionellt manliga yrkena.

På vårdarbetsplatserna fann vi inga signifikanta skillnader mellan kvinnors och mäns befattningar, löner eller övriga arbetsvillkor, men kategoriseringen i "kvinnor" och "män" hade likafullt betydelse. På dessa arbetsplatser uttryckte flera av dem vi intervjuade en positiv inställning till att ha män anställda inom traditionella kvinnoyrken och uttryckte att "blandade" grupper var att föredra framför grupper med enbart kvinnor. Flera informanter talade om fördelar med manliga anställda: de ansågs vara fysiskt starkare, och de boende ansågs uppskatta dem: "Dom boende tycker att det är roligt med män många gånger, dom gamla tanterna." Det fanns dock kvinnliga boende som inte accepterade att manliga anställda hjälpte dem med deras personliga hygien.

En annan uppfattad könsskillnad liknade den som en informant på Bostadsbolaget tog upp i citatet ovan, nämligen att det var bättre att jobba med män därför att de var "rakare", medan kvinnor ofta var "tjafsiga". Kvinnliga anställda nämnde bland annat "baktal och rykten" i samarbetet mellan kvinnor, att det inte var "lika mycket tjafs" när de jobbade med en man, att killarna inte var "tjafsiga som vi kvinnor är" och att vissa kvinnor var "kärringar". Flera manliga undersköterskor och sjukvårdsbiträden instämde i denna negativa bild av kvinnors sätt 
att kommunicera, refererade till "mycket skitsnack", "tjafs" och "kärringsnacket" eller hävdade att män var "mer raka mot varandra".

Vi fann även andra mönster. Flera intervjupersoner framförde att det inte fanns någon skillnad mellan hur kvinnor och män jobbade eller vad de gjorde, och det förekom också viss kritik mot män i allmänhet, framför allt om att de skulle vara slarviga. Några informanter menade, med irritation, att män favoriserades genom att de sågs som duktiga bara de skötte sina normala arbetsuppgifter. Sammantaget fanns dock på vårdarbetsplatserna en tydlig tendens att på vissa sätt höja upp män över kvinnor. Detta gjordes av både kvinnor och män.

Gränsdragningen mellan "svenskar" och "invandrare" förekommer i många sammanhang i Sverige. Den aktualiserades i vissa diskussioner på Bostadsbolaget. När informanterna talade om andra anställda delade de inte in dem i "svenskar" och "invandrare". Dock återkom kommentarer om vad vissa uppfattade som invandrade kollegers bristande språkkunskaper. De ansågs skapa merarbete; en fastighetsskötare sa: "Min närmaste kollega [...] pratar jättedålig svenska och så får jag mycket samtal som har med [kollegans] jobb att göra." Språket medförde också att de utlandsfödda kollegerna hamnade utanför arbetsplatsens gemenskap, menade några. Invandrade från samma språkområde blev emellanåt kategoriserade som "x-talande" och när de talade sitt modersmål på arbetsplatsen kunde det väcka starkt negativa känslor:

Vi gillar inte att dom pratar [sitt modersmål] här på jobbet [...] Det tycker inte jag är schyst [när några talar om jobbet på ett annat språk än svenska], det är dålig respekt på ett sätt [...] Han har varit här i 25 år och pratar väldigt dålig svenska, det tycker jag är skämmigt.

Vanligare på Bostadsbolaget var att de anställda talade om hyresgäster som "invandrare" och om de olika bostadsområdena som mer eller mindre "invandrartäta". När intervjuaren bad en fastighetsskötare att beskriva hur det var i ett visst bostadsområde, vilka människor som bodde där, blev svaret: "Det är ju inte så stor blandning här. Det finns ju invandrarinslag, det gör det." En annan svarade: "Det finns invandrare men det är inte invandrartätt." Ibland betraktades "invandrartäthet" som något problematiskt, ibland inte. Denna gränsdragning kan ha 
spillt över på relationerna mellan fastighetsskötare från olika delar av världen. Vi såg dock inga tydliga tecken på att de svenskfödda anställda utnyttjade kategoriseringen för att monopolisera resurser.

Gränsdragningen mellan "invandrare" och "svensk" kom till tydligare uttryck på äldreomsorgsarbetsplatserna. De flesta av vårdbiträdena och undersköterskorna svarade nej på vår intervjufråga om ifall det var någon skillnad mellan att jobba tillsammans med en svenskfödd eller en utlandsfödd kollega. Flera uttryckte att de varken föredrog det ena eller det andra. Men det fanns också en annan tendens. Vissa svenskfödda undersköterskor och vårdbiträden talade om viktiga olikheter:

Det finns kulturella skillnader. Det finns det. Man kan inte komma ifrån det, förstår du. Det finns djupt inom en, om man är född i ett annat land. Då är man liksom ändå den personen och har dom värderingarna, från början.

Denna informant berättade också om känslan av samhörighet med andra "svenskar": "Alltså ... vi behöver inte säga så mycket till varandra, vi som är svenskar, så att säga. Vi förstår varandra ändå."

En annan anställd svarade på frågan varför hon helst jobbade med "svenskar": "För att det är dom som kan språket och det är dom som kan kulturen. Tyvärr, det är faktiskt så. Det är enorma kulturskillnader fast man inte tror det."

Citaten ovan är hämtade från intervjuerna, men kategoriseringen i "svenskar" och "invandrare" kom också till uttryck i vardagliga interaktioner mellan de anställda, som denna fältanteckning visar:

A [en invandrad kvinna] vänder sig till B [en svenskfödd] och frågar: "Visst vi invandrare är knäppa, eller hur?" "Nej, nej ... inte alls", understryker B [som är den enda i samtalet som är svenskfödd]. Skämten fortsätter.

Flera svenskfödda anställda gjorde inte bara skillnad mellan sig själva och andra, utan intog också en negativ attityd till invandrade kolleger. Oftast gällde det att de ansåg att vissa kolleger hade otillräckliga 
språkkunskaper och att det försvårade arbetet. Men flera andra negativa generaliseringar framkom:

Jag har ingenting emot utlänningar, eller invandrare, får man kanske säga. Jag har ingenting emot dom men här är bara nästan utländsk arbetskraft. Och dom lever ju sina liv. Det är familjer och släkten. Dom lever ju mest med sin släkt och sina barn. Dom är inte lika mycket utåtriktade som vi svenskar är och kanske vill träffas utanför jobbet och gå ut och äta, gå på teater och gå ut och dansa. Eller exempelvis åka iväg på en kryssning tillsammans. Då ska dom ha tillåtelse, jag antar det, från sin man och släkten också.

En svenskfödd man menade att utrikesfödda inte ville erkänna när de gjort fel, till skillnad från "svenskar". En av de svenskfödda kvinnor som vi har citerat ovan hävdade att de som "kommer från Iran och såna länder, dom har mer temperament än vad vi har", vilket hon menade ledde till konflikter.

Gränsdragningen var märkbar för den invandrade personalen. En informant från ett land i det globala syd kände att de på arbetsplatsen var "två grupper: en grupp svenskar och en grupp utländska". Flera informanter berättade om tillfällen då de pekats ut på ett negativt sätt eller hånats för att de inte kunde tala eller skriva svenska som modersmålstalarna:

Ibland sitter man och läser rapporter på [den elektroniska plattform som användes på avdelningen]. Om någon har skrivit lite fel, något stavfel ... "Ha ha ha", sitter dom och skrattar. [...] Man blir jätteledsen, du vet. Dom säger "utländskarna". Jag hatar det här ordet. Visst är jag utlänning, men dom behöver inte påpeka hela tiden, eller dom säger att "Ni har konstiga namn".

I beskrivningen drar den svenskfödda personalen gränsen tydligare kring sig själva genom att markera att det är de som kan svenska ordentligt, till skillnad från "utlänningarna", som även har konstiga namn. Under den deltagande observationen observerade vi situationer då infödda svenskar använde språket som en relativt fientlig skillnadsmarkör gent- 
emot utlandsfödda kolleger som mycket väl kunde göra sig förstådda men inte alltid uttryckte sig helt "korrekt".

Oavsett om de svenskfödda anställda som drog kategoriska gränser mellan sig själva och andra avsåg att monopolisera resurser eller inte, fick det ibland den konsekvensen. En anställd hade blivit flyttad från en avdelning till en annan, där hon blev teamledare med det viktiga ansvaret att planera personalens arbetsschema. Fältarbetet och intervjuerna visade att flera informanter kritiserade henne för att diskriminera invandrad personal. En anklagelse gällde att hon särbehandlade de svenskfödda undersköterskorna och vårdbiträdena positivt genom att ge dem bättre möjligheter att byta tider och få extratimmar när de så önskade. Hon anklagades också för rasistiska uttalanden. Det skapade oro och upprördhet på avdelningen. Att kvinnan sedan tidigare var känd för detta slags beteende var inget den svenskfödda avdelningschefen betraktade som ett hinder för att låta henne bli teamledare. Tvärtom såg hon det som en bra lösning på ett problem:

Passar man inte i en grupp måste man få prova någon annan, för att jag tror att alla människor passar någonstans. [...] Jag kan bara ta ett exempel: I huset så hade vi en person, hon har varit på flera avdelningar, och det var jättenegativt kring henne, det var en hel del bråk, hon har varit negativ mot vår invandrade personal och framför allt mot yngre invandrare. Och så helt plötsligt fick hon en annan position på en annan avdelning. Alltså, det strålar av den här kvinnan nu. Man ser att hon tycker att det är roligt nu.

Om kritiken mot den nya teamledaren hade fog för sig bidrog denna avdelningschef till att dra en gräns kring den "svenska" kategori som hon själv ansåg sig tillhöra och till att den svenskfödda personalen kunde monopolisera bättre schematider och extrainkomster. (Jämför beskrivningarna av hur chefer agerar när rasism eller diskriminering kommer på tal i Selberg, kapitel 4 och Sahroui, kapitel 6.)

En annan typ av monopolisering var ännu viktigare. Anställda från det globala syd, som hade signifikant lägre löner och befattningar, hade även sämre tillgång än andra anställda till socialt kapital på arbetsplatsen. Med det avser vi de relationer som kan hjälpa en anställd att få bland 
annat viktig information, tips om möjligheter till interna utbildningar och hjälp att göra karriär. Viktigast för ens sociala kapital på arbetsplatsen är vanligen relationer med personer som har högre befattningar.

Denna skillnad framkom när vi i enkäten bad respondenterna ange vilken utbildningsnivå och vilka positioner de kolleger hade som de kände störst förtroende för och vars råd de litade på. Det visade sig att anställda från det globala syd hade en mindre andel personer i högre befattningar (såsom sjuksköterskor och läkare) i sina sociala nätverk. Det påverkade deras löner. Enligt vår statistiska analys av materialet förklarade tillgången till arbetsplatsspecifikt socialt kapital en del av löneskillnaden mellan anställda från det globala syd och övriga anställda. Eftersom gruppen svenskfödda innehade en oproportionerligt hög andel av de högre befattningarna var personalen från det globala syd också relativt utestängd från de nätverk där infödda umgicks. Att de anställda från det globala syd led brist på resursstarka kontakter på sin arbetsplats hängde därför med stor sannolikhet samman med den kategoriska gränsdragningen. Det fanns alltså svenskfödda anställda som kände sig främmande inför eller ogillade sina invandrade kolleger, vilket säkert stod klart för de senare, inte minst om de drabbats av diskriminerande beteende. Detta bidrog sannolikt till att svenskfödda och invandrade anställda tenderade att umgås i skilda grupper.

Nu kan vi sammanfatta svaret på den andra forskningsfrågan, hur ojämlikhet mellan olika grupper upprätthölls på arbetsplatserna, tillsammans med svaret på den första frågan i tabell 9.1. Vi kallar de relationella förklaringarna för "troliga" eftersom det är mycket svårt att säkert fastställa samband mellan relationer på en arbetsplats och typer av ojämlikhet. 
Tabell 9.1. Ojämlikheter på mans- och kvinnodominerade arbetsplatser och troliga relationella förklaringar

\begin{tabular}{|c|c|c|}
\hline & $\begin{array}{l}\text { Bostadsbolaget: } \\
\text { mansdominerad arbetsplats }\end{array}$ & $\begin{array}{l}\text { Äldreomsorgen: } \\
\text { kvinnodominerade arbetsplatser }\end{array}$ \\
\hline \multirow[t]{2}{*}{$\begin{array}{l}\text { Ojämlikheter mellan } \\
\text { kvinnor och män }\end{array}$} & $\begin{array}{l}\text { Svenskfödda kvinnliga } \\
\text { fastighetsskötare tjänade } \\
\text { mindre än svenskfödda manliga } \\
\text { fastighetsskötare. }\end{array}$ & \\
\hline & $\begin{array}{l}\text { Kvinnor kände större osäkerhet än } \\
\text { män ifråga om att framföra kritik på } \\
\text { arbetsplatsen. }\end{array}$ & \\
\hline $\begin{array}{l}\text { Troliga relationella } \\
\text { förklaringar }\end{array}$ & $\begin{array}{l}\text { Kategorisk gränsdragning } \\
\text { mellan kvinnor och män och viss } \\
\text { nedvärdering av kvinnor. }\end{array}$ & \\
\hline \multirow[t]{3}{*}{$\begin{array}{l}\text { Ojämlikheter mellan } \\
\text { invandrade och infödda } \\
\text { anställda }\end{array}$} & $\begin{array}{l}\text { Invandrade anställda var } \\
\text { underrepresenterade i högre } \\
\text { och överrepresenterade i lägre } \\
\text { befattningar. }\end{array}$ & $\begin{array}{l}\text { Anställda från det globala syd } \\
\text { var underrepresenterade i högre } \\
\text { och överrepresenterade i lägre } \\
\text { befattningar. }\end{array}$ \\
\hline & $\begin{array}{l}\text { Invandrade fastighetsskötare } \\
\text { tjänade mindre än infödda. }\end{array}$ & $\begin{array}{l}\text { Anställda från det globala syd } \\
\text { tjänade mindre än andra i samma } \\
\text { befattningar. }\end{array}$ \\
\hline & $\begin{array}{l}\text { Invandrade anställda kände större } \\
\text { osäkerhet än infödda ifråga om att } \\
\text { framföra kritik på arbetsplatsen. }\end{array}$ & $\begin{array}{l}\text { Anställda från det globala syd } \\
\text { kände större osäkerhet än andra } \\
\text { anställda ifråga om att framföra } \\
\text { kritik på arbetsplatsen. }\end{array}$ \\
\hline \multirow[t]{5}{*}{$\begin{array}{l}\text { Troliga relationella } \\
\text { förklaringar }\end{array}$} & $\begin{array}{l}\text { Lönemässig premiering av den } \\
\text { individuella kompetensen att } \\
\text { behärska svenska väl. }\end{array}$ & $\begin{array}{l}\text { Anställda med föregivet bristande } \\
\text { individuell kompetens i svenska } \\
\text { riskerar att förlora anställning } \\
\text { eller omplaceras. }\end{array}$ \\
\hline & $\begin{array}{l}\text { Icke-premiering av den individuella } \\
\text { kompetensen kunskaper i andra } \\
\text { språk som utnyttjas i arbetet. }\end{array}$ & \multirow{2}{*}{$\begin{array}{l}\text { Avsaknad av krav på } \\
\text { lönekartläggning ger sämre } \\
\text { möjlighet för invandrade att driva } \\
\text { lönekrav på gruppbasis. }\end{array}$} \\
\hline & $\begin{array}{l}\text { Avsaknad av krav på } \\
\text { lönekartlägning ger sämre }\end{array}$ & \\
\hline & $\begin{array}{l}\text { möjlighet för invandrade att driva } \\
\text { lönekrav på gruppbasis. }\end{array}$ & $\begin{array}{l}\text { Kategorisk gränsdragning } \\
\text { mellan infödda och invandrade, } \\
\text { ibland med negativ behandling } \\
\text { av invandrade och positiv av } \\
\text { infödda. }\end{array}$ \\
\hline & & $\begin{array}{l}\text { Monopolisering av } \\
\text { arbetsplatsspecifikt socialt kapital. }\end{array}$ \\
\hline
\end{tabular}




\section{Likheter och skillnader mellan ojämlikhetsregimerna}

Vi fann betydande likheter mellan den mansdominerade arbetsplatsen och de kvinnodominerade arbetsplatserna i de aspekter av ojämlikhetsregimerna som gällde missgynnandet av utlandsfödda anställda, i synnerhet av personer som invandrat från det globala syd. Dessa anställda missgynnades befattnings- och lönemässigt och de kände större osäkerhet när det gällde att framföra kritik på sina arbetsplatser. Ifråga om ojämlikhet mellan kvinnor och män fann vi däremot en viktig skillnad: endast på den mansdominerade arbetsplatsen fanns tecken på att kvinnor var missgynnade, och då endast i relation till svenskfödda män.

Vi har sökt förklara ojämlikheterna ur ett relationellt perspektiv. De invandrades sämre ställning $i$ båda typer av ojämlikhetsregim kunde vi delvis förklara genom att analysera resursanspråk och social stängning. På båda typerna av arbetsplats värderades kompetensen goda svenskkunskaper på ett sätt som synbarligen missgynnade invandrade anställda. På vårdarbetsplatserna iakttog vi hur den brist i svenska som cheferna uppfattade hos några anställda förpassade dem till befattningar med lägre lön. På Bostadsbolaget var det tydligt att kunskaper i andra språk - som flitigt användes i arbetet - inte premierades (för andra relevanta beskrivningar av språkfrågornas roll på svenska arbetsplatser, se Lill, kapitel 3 och Selberg, kapitel 4). I avsnittet om gruppmakt pekade vi på bristen på lagstadgade åtgärder utöver diskrimineringslagstiftningen för att stävja ojämlikhet mellan anställda från olika delar av världen.

På båda typerna av arbetsplats fann vi också att gränser drogs mellan invandrade och infödda. Kategorisk gränsdragning kring svenskhet såg vi speciellt i äldreomsorgen, där vi också fann en möjlig koppling till exkludering från bättre schematider och extrapass samt till exkludering från sociala nätverksresurser som var kopplade till högre lön. Kategorisering och monopolisering som missgynnade anställda från det globala syd framstod tydligare där än på Bostadsbolaget. Har det att göra med att Bostadsbolaget var mansdominerat och vårdarbetsplatserna var kvinnodominerade?

Möjligen är det så, men vi ser även andra, kanske troligare, förklaringar. Vi kan ha fångat upp olika mycket av de sociala processer som 
pågick på de olika arbetsplatserna. Vi använde delvis olika intervjufrågor i de båda studierna och vi gjorde mer omfattande deltagande observationer i äldreomsorgen än på Bostadsbolaget. Intervjuareffekter kan också ha påverkat resultatet: i studien av Bostadsbolaget var vi två svenskfödda forskare, medan i studien av vårdarbetsplatserna även ingick forskare från det globala syd. Invandrade anställda kan ha varit mer benägna att berätta om upplevelser av diskriminering för intervjuare de kanske tänkte sig hade liknande erfarenheter själva.

Men det är också möjligt att diskriminering och ojämlikhet faktiskt var större problem i äldreomsorgen. Det skulle kunna vara en effekt av att arbetsmiljön var hårdare där. På båda typerna av arbetsplats talade många informanter om stress och tidspress, men fastighetsskötaryrket beskrev de flesta som fritt. Fastighetsskötarna planerade själva och la upp sin egen arbetsdag. Undersköterskorna och sjukvårdsbiträdena var däremot hårt styrda i sina arbetsuppgifter och hade strikta och ofta obekväma scheman. I äldreomsorgen krävdes dessutom att kollegerna samarbetade mer om uppgifterna, något som kan leda till större slitningar mellan människor.

Vi har funnit det svårare att förklara varför kvinnor missgynnades på vissa sätt på Bostadsbolaget. Gränsdragning mellan kvinnor och män förekom, liksom i resten av samhället, på alla de undersökta arbetsplatserna. Både på den mansdominerade arbetsplatsen och på de kvinnodominerade förekom det att kategoriseringen användes i sammanhang där kvinnor ifrågasattes (de kvinnliga fastighetsskötarnas förmåga att reparera ifrågasattes och kvinnliga anställdas sätt att kommunicera kritiserades), men det var bara på den mansdominerade vi iakttog att kvinnor missgynnades mer konkret. Kanske har teorin om tokenism ändå något för sig när den grupp som missgynnas både utgör en minoritet på arbetsplatsen och är missgynnad i samhället i stort.

Det analysen inte alls förklarar är varför män inte hade signifikant bättre villkor på de kvinnodominerade arbetsplatserna. Utifrån den tidigare forskning vi presenterade i avsnittet om glastak och glasrulltrappor förmodade vi att de skulle ha det. Varför tog inte svenskfödda manliga anställda glasrulltrappan uppåt på de kvinnodominerade arbetsplatserna? I synnerhet som vi fann inslag i relationerna som skulle ha kunnat bidra till att förklara manliga privilegier: vissa förment man- 
liga egenskaper upphöjdes över kvinnors sätt att vara och män ansågs speciellt nyttiga för att utföra tekniska uppgifter, medan inga specifika nyttiga "kvinnliga" färdigheter framhävdes.

Svaret på frågan har att göra med de olika arbetsplatsernas specifika normer och historia, men kanske också med mer generella förhållanden, såsom den minskning av lönegapet mellan kvinnor och män som pågår sedan flera år på svensk arbetsmarknad (Medlingsinstitutet 2019). En förklaring till löneutjämningen är att fler kvinnor blir chefer och att män i större utsträckning kommit in i kvinnodominerade yrken, en annan kan vara de lagstadgade kraven på lönekartläggningar för att uppdaga omotiverade skillnader mellan mäns och kvinnors löner. Ojämlikhetsregimer kan förändras både inifrån arbetsplatserna och med påverkan av det större samhälle där de ingår.

Vad gäller de ojämlikhetsregimer som missgynnar anställda från det globala syd (och i mindre utsträckning andra invandrade personer) ser vi när detta skrivs inga tecken på samhällsförändringar som skulle verka för större jämlikhet på enskilda arbetsplatser. Tvärtom finns det många tecken på att rasismen växer i Sverige. Desto viktigare är det att forska vidare om hur ojämlikhetsregimerna upprätthålls och att påminna om det som Birnbaum slår fast i kapitel 14: ojämlika arbetsplatser är orättvisa arbetsplatser.

\section{Noter}

1 Den studie av äldrevårdsarbetsplatser som omtalas i texten är genomförd inom ramen för ett projekt bekostat av Vetenskapsrådet: "Jämlika arbetsplatser i en ojämlik värld. En studie av vad som befrämjar könsmässig och etnisk jämlikhet på svenska arbetsplatser". (VR-projekt 421-2010-1499)

2 Vi använder genomgående ordet "invandrad" hellre än "invandrare" för att tydliggöra att det handlar om något som hänt, inte en pågående process. På det sättet synliggör vi också hur de som invandrat blir till kategorin "invandrare", och deras barn ofta till kategorin "andra generationens invandrare" trots att de aldrig själva invandrat (för diskussion se t.ex. Brune 2004, Knocke 2006).

3 Alla översättningar från engelska i kapitlet är författarnas.

4 Alla intervjuer och fokusgruppsamtalen transkriberades, och vi bearbetade transkriberingarna med hjälp av dataanalysprogrammet Max QDA. I analysen tematiserade vi intervjusvaren utifrån våra forskningsfrågor, och tillämpade också en mer induktiv ansats där vi noterade oförutsedda teman som dök upp i materialet. 
5 Alla intervjuer, liksom fältanteckningarna från den deltagande observationen, transkriberades, och vi bearbetade dem med hjälp av dataanalysprogrammet NVivo11. Analysen var snarlik den vi genomförde på materialet från Bostadsbolaget.

6 Detaljerat sifferunderlag till uppgifterna i detta avsnitt och tabeller som preciserar uppgifterna finns i Boréus \& Mörkenstam (2010) och Behtoui m.fl. (2017, 2020).

7 Enkätfrågan lydde: "Händer det i din nuvarande situation på arbetsplatsen att du är rädd för att uttrycka dig kritiskt mot något på Bostadsbolaget på möten eller till chefer?"

8 Enkätfrågan lydde: "Känner du att du kan framföra kritik av förhållanden på din arbetsplats till din chef?"

\section{Referenser}

Acker, J. (1990) "Hierarchies, jobs, bodies: a theory of gendered organization", Gender \& Society 4(2):139-158.

Acker, J. (2006) "Inequality regimes. Gender, class and race in organizations", Gender \& Society 20(4):441-464.

Acker, J. (2009) "From glass ceiling to inequality regimes", Sociologie du Travail 51(2):199-217.

Behtoui, A., \& Neergaard, A. (2010) "Social capital and wage disadvantages among immigrant workers", Work, Employment and Society 24(4):761-779.

Behtoui, A., Boréus, K., Neergaard, A. \& Yazdanpanah, S. (2016) "Valet mellan protest, sorti och tystnad för invandrade och infödda anställda i äldrevården". I M. Holmqvist (red.) Makt och inflytande i arbetslivet. Stockholm: Premiss förlag.

Behtoui, A., Boréus, K., Neergaard, A. \& Yazdanpanah, S. (2017) "Speaking up, leaving or keeping silent: Racialized employees in the Swedish elderly care sector", Work, Employment and Society 31(6):954-971.

Behtoui, A., Boréus, K., Neergaard, A. \& Yazdanpanah, S. (2020) "Why are care workers from the global south disadvantaged? Inequality and discrimination in Swedish elderly care work", Ethnic and Racial Studies 43(16):155-174.

Boréus, K. \& Mörkenstam, U. (2010) Spjälorna i buren. En arbetsplatsstudie av ojämlikhet mellan kvinnor och män, invandrade och infödda. Lund: Studentlitteratur.

Boréus, K. \& Mörkenstam, U. (2015) "Patterned Inequalities and the Inequality Regime of a Swedish Housing Company", Nordic Journal of Working Life Studies 5(4):105-124.

Brune, Y. (2004). Nyheter från gränsen: Tre studier i journalistik om "invandrare", flyktingar och rasistiskt våld. Göteborg: Göteborgs universitet, Institutionen för journalistik och masskommunikation.

Budig, M. (2002) "Male advantage and the gender composition of jobs: Who rides the glass escalator?", Social Problems 49(2):258-277.

Bursell, M. (2019) "Arbetsmarknaden - integration, segregation och diskriminering". I Å. Sandberg (red.) Arbete \& välfärd. Ledning, personal och organisationsmodeller i Sverige. Lund: Studentlitteratur.

Diskrimineringsombudsmannen (2020), Gör en lönekartläggning varje år. https:// www.do.se/framja-och-atgarda/arbetsgivarens-ansvar/lonekartlaggning/. 
Erlandsson S., Storm P., Stranz A., Szebehely M. \& Trydegård G. B. (2013) "Marketising trends in Swedish eldercare: competition, choice and calls for stricter regulation". I G. Meagher \& M. Szebehely (red.) Marketisation in Nordic eldercare: a research report on legislation, oversight, extent and consequences. Stockholm: Stockholms universitet.

Hagerman, H., Engström, M., Häggström, E., Wadensten, B. \& Skytt, B. (2015) "Male first-line managers' experiences of the work situation in elderly care: an empowerment perspective", Journal of Nursing Management 23:695-704.

Hörnqvist, M. (2019) "Klasstruktur och arbetets organisering". I Å. Sandberg (red.) Arbete \& välfärd. Ledning, personal och organisationsmodeller i Sverige. Lund: Studentlitteratur.

Kjellberg, A. (2019) "Den svenska partsmodellen utmanad - facket, arbetsgivarna och lönebildningen”. I Å. Sandberg (red.) Arbete \& välfärd. Ledning, personal och organisationsmodeller i Sverige. Lund: Studentlitteratur.

Knocke, W. (2006). "Den strukturella diskrimineringens försåtlighet: Ett historiskt och nutida perspektiv". I A. Neergaard (red.), På tröskeln till lönearbete: Diskriminering, exkludering och underordning av personer med utländsk bakgrund, SOU 2006:60. Stockholm: Fritzes.

le Grand, C. \& Szulkin, R. (2002) "Permanent disadvantage or gradual integration: Explaining the immigrant-native earnings gap in Sweden", Labour Studies Journal 16(1):37-64.

Malin, L. \& Wise, R. (2018) "Glass ceilings, glass escalators and revolving doors". I G. Ritschard \& M. Studer (red.) Sequence analysis and related approaches. Innovative methods and approaches. Cham: Springer Open.

Martin, P. Y. (2003) "'Said and done' versus 'saying and doing': gendering practices, practicing gender at work", Gender \& Society 17(3):342-366.

Medlingsinstitutet (2019) Löneskillnader mellan kvinnor och män 2018. Vad säger den officiella statistiken? Stockholm: Medlingsinstitutet.

Moss Kanter, R. (1993/1977) Men and women of the corporation. New York: Basic Books.

Mulinari, P. (2015) "Exploring the experiences of women and migrant medical professionals in Swedish hospitals: Visible and hidden forms of resistance", Equality, Diversity and Inclusion: An International Journal, 34(8):666-677.

O’Reilly, J., Smith, M., Deakon, S. \& Burchell, B. (2015) "Equal pay as a moving target: International perspectives on forty-years of addressing the gender pay gap", Cambridge Journal of Economics 39:299-317.

Ott, M. E. (1989) "Effect of the male/female ratio at work: Policewomen and Male Nurses", Psychology of Women Quarterly 13:41-57.

Reskin, B. F. \& Bielby, D. D. (2005). "A sociological perspective on gender and career outcomes", The Journal of Economic Perspectives, 19(1):71-86.

Rödin, M. (2011) Gender, ethnicity and labor market disparities. Stockholm: Stockholms universitet.

Stainback, K., Tomaskovic-Devey, D. \& Skaggs, S. (2010) "Organizational approaches to inequality: Inertia, relative power, and environments", Annual Review of Sociology 36:225-247.

Tilly, C. (1998) Durable inequality. Berkeley: University of California Press. 
Tomaskovic-Devey, D. (2014) "The relational generation of workplace inequalities", Social Currents 1(1):51-73.

Tomaskovic-Devey, D. \& Avent-Holt, D. (2019) Relational inequalities: An organizational approach. Oxford Scholarship Online: January 2019 DOI: 10.1093/ oso/9780190624422.001.0001.

Williams, C. L. (1992) "The glass escalator: Hidden advantages for men in the "female" professions, Social Problems 39:253-267.

Williams, C. L. (red.) (1993)."Doing "women's work": men in nontraditional occupations. Newbury Park: Sage.

Williams, C. L. (2013) "The glass escalator revisited: Gender inequality in neoliberal times, SWS Feminist Lecturer", Gender \& Society, 27(5):609-629.

Woodhams, C. (2015) "The presence of ethnic minority and disabled men in feminised work: Intersectionality, vertical segregation and the glass escalator", Sex Roles (72)7-8:277-293.

Yavorsky, J.E., Cohen, P.N. \& Qian, Y. (2016) "Man up, man down: Race-ethnicity and the hierarchy of men in female-dominated work", The Sociologist Quarterly 57(4):733-758.

Yoder, J. D. (1991). "Rethinking tokenism: looking beyond numbers", Gender \& Society 5(2):178-192.

Åslund, O. \& Nordström Skans, O. (2010) "Will I see you at work? Ethnic workplace segregation in Sweden, 1985-2002", ILR Review 63(3):471-493. 